\title{
Information and Communication Technology Adoption in Small- and Medium-Sized Enterprises: Demographic Characteristics*
}

\author{
Hadri KUSUMA ${ }^{1}$, Muafi MUAFI ${ }^{2}$, Hendy Mustiko AJI ${ }^{3}$, Sigit PAMUNGKAS ${ }^{4}$ \\ Received: August 01, 2020 Revised: September 06, 2020 Accepted: September 10, 2020
}

\begin{abstract}
This study examines the acceptance factors, barriers, benefits, and strategies for resolving Information and Communication Technology (ICT) adoption and usage problems based on the different demographic characteristics of SMEs. The demographic characteristics investigated are gender, educational qualifications, age, managerial status, and years of business experience. To the best of our knowledge, this paper is the first to examine a more comprehensive demographic characteristics in the context of ICT adoption. A survey using selfadministered questionnaires was conducted to retrieve information from SME owners/managers in Pekalongan, the local city of Indonesia. The items in the questionnaire were discussed with various experts in the field and a pilot study was conducted prior to the distribution of the research instrument. The study made some interesting findings. No significant differences were found in the SMEs' adoption factors between the demographics of gender groups and educational qualifications. However, significant disparities were found to exist among the age compositions, managerial status, and years in business. Additionally, younger managers/owners of SMEs find it easier to understand the background factors of ICT adoption. Lastly, older managers/owners are more likely to stick to the organizational status quo, be less able to learn new technology, and more likely to avoid risky decisions.
\end{abstract}

Keywords: Demographic Characteristics, Technology Acceptance Model, Technology Acceptance Benefits, Technology Acceptance Barriers

JEL Classification Code: O33, M15, M13, M40

\section{Introduction}

Along with the advancement and ubiquitous access to Information and Communication Technology (ICT), enterprises are increasingly dependent on ICT adoption in

\footnotetext{
*Acknowledgements:

This research is fully funded by The Ministry of Research, Technology and Higher Education (Kemenristekdikti), The Republic of Indonesia under the Basic Research Grant scheme for 2019/2020.

${ }^{1}$ First Author and Corresponding Author. Professor, School of Accounting, Universitas Islam Indonesia, Indonesia [Postal Address: Jalan Prawiro Kuat, Condong Catur, Depok, Sleman, Yogyakarta, 55283, Indonesia] Email: 883120104@uii.ac.id

${ }^{2}$ Professor, School of Management, Universitas Islam Indonesia. Email: muafi@uii.ac.id

${ }^{3}$ Lecturer, School of Management, Universitas Islam Indonesia.

Email: hm.aji@uii.ac.id

${ }^{4}$ Lecturer, School of Accounting, Universitas Islam Indonesia.

Email: sigit.pamungkas@uii.ac.id

(c) Copyright: The Author(s)

This is an Open Access article distributed under the terms of the Creative Commons Attribution Non-Commercial License (https://creativecommons.org/licenses/by-nc/4.0/) which permits unrestricted non-commercial use, distribution, and reproduction in any medium, provided the original work is properly cited.
}

various aspects of daily life. In the context of the business and economic environment, ICT adoption is regarded as an essential requirement for driving economic growth in the current global business environment (Okundaye et al., 2019). ICT is thus an essential tool to support business organizations, at any scale, in their ability to adapt to the various aspects of technology revolution, such as digitalization in modern business practices. Digitalization has enabled an increasingly rapid flow and growth of information, which requires more advanced and flexible ICT support (Van Wart et al., 2017). However, the pace of ICT change is not easy to predict, which means that business organizations must keep pace with technological changes in order to maintain their competitiveness (Nguyen et al., 2020).

The existing literature documents studies on ICT adoption in both developed nations (for example, Meggiolaro, 2018; Ono \& Zavodny, 2005; Landstrom, 1993) and emerging countries (for example, Al-weshah \& Al-zubi, 2012; TobOgu, Kumar, \& Cullen, 2018; Ndiege, Herselman, \& Flowerday, 2014). More importantly, the literature also cites a considerable number of works on the background factors of acceptance, barriers, benefits, and strategies to resolve 
factors (for example, Okundaye et al., 2019; Tan, Chong, Lin, \& Eze, 2010; Ongori \& Migiro, 2010). However, despite the growing number of studies that have examined ICT adoption in different contexts, none have considered the background factors of ICT adoption and their relationship to demographic characteristics. The theories of agency (Jensen \& Meckling, 1976), human capital (Becker, 1964) and upper echelon (Hambrick \& Mason, 1984) suggest that ICT adoption backgrounds could differ according to firm characteristics. The general purpose of this study is therefore to investigate the relationship between the demographic characteristics of SMEs and the background factors of their ICT adoption. Especially, the objective of the research is to examine the acceptance factors, barriers, benefits, and strategies to resolve ICT adoption based on the different demographic characteristics of SMEs, with a focus on the case of Indonesian SMEs in the batik industry. The demographic characteristics investigated are gender, educational qualifications, age, managerial status, and years of business experience.

The paper makes several additional contributions. Theoretically, this study identifies whether ICT adoption backgrounds can be expected to vary depending on demographic characteristics, in addition to taking into account why this might be the case. To the best of our knowledge, this paper is also the first to examine demographic characteristics and ICT adoption backgrounds in Indonesia. In addition to examining the acceptance and barrier factors of ICT adoption, the paper investigates broader adoption backgrounds, including the benefits of and strategies for resolving ICT adoption problems. Finally, this study contributes to the literature on SMEs as it is the first to ascertain the relationship between the demographics and ICT adoption background of SMEs. This study provides useful insight for government and other stakeholders seeking to identify the factors relevant to improving the competitiveness of Indonesian SMEs in the global market.

The next section presents the concept of SMEs and the grand theories that underpin the proposed hypotheses. Section 3 presents the research design that guides this study, explains the methodology adopted to conduct the analysis, and presents the hypothesis formulation in this research. The empirical findings and analyses are discussed in Section 4.
To conclude, Section 5 summarizes the results of this study, emphasizes the implications of the findings, acknowledges its limitations, and provides recommendations and extension for future studies.

\section{SMEs, Theories, and Previous Studies}

This section introduces the concept of SMEs and the application to the batik industry in Indonesia. This is followed by a discussion of the overarching theories, previous studies, research model, and proposed hypotheses.

\subsection{SMEs In Indonesia}

There is no universally-accepted global standard definition for small- and medium-sized enterprises (SMEs) to be found. As such, SMEs are defined differently in crossnational laws and their dimensions are relative to the size of each country's domestic economy. Additionally, a firm's classification as an SME can be based on the country in which it operates, along with various other characteristics such as annual sales, number of employees, and its assets, or indeed any combination of such features (Institute, 2019).

SMEs in Indonesia are regulated under Act Number 20, 2008 (Indonesian Government, 2008). Article 1 contains a breakdown of SME definitions, with smallsized enterprises (SEs) described as stand-alone productive economic enterprises run by individuals or business entities that are not subsidiaries or branches of companies that are owned, controlled, or part of, either directly or indirectly, a medium or large enterprise, and that meet the criteria of an SE as referred to in the Act. Medium-sized enterprises (MEs), meanwhile, are defined as independent, productive economic enterprises carried out by individuals or business entities that are not subsidiaries or branches of companies that are owned, controlled, or part of, either directly or indirectly, SEs or large enterprises (LEs), according to the criteria stated in the Act. The criteria outlined in Act Number 20, 2008 are further explained in Article 6, which classifies the types of SMEs based on their annual sales or net asset values, although this does not include land and buildings used as business premises. The classification is illustrated in Table 1.

Table 1: Criteria of Indonesian SMEs (in IDR)

\begin{tabular}{|c|c|c|}
\hline Enterprise Category & Annual Sales & Net Assets \\
\hline Enterprises (SEs) & Rp $300,000,000$ up to $\operatorname{Rp} 2,500,000,000$ & $\operatorname{Rp} 50,000,000$ up to $\operatorname{Rp} 500,000,000$ \\
\hline Medium Enterprises (MEs) & $\operatorname{Rp} 2,500,000,000$ up to $\operatorname{Rp} 50,000,000,000$ & $\operatorname{Rp} 500,000,000$ up to $\operatorname{Rp} 10,000,000,000$ \\
\hline
\end{tabular}

Source: Act Number 20, 2008 
The existence of SMEs in Indonesia is an interesting phenomenon. Temporary statistics released by the Indonesian Government illustrate the growth in the number of SMEs, which have come to account for a 99.9 percent share of the national business. These SMEs comprise at least $62,922,617$ business units, compared to only 5,460 large-scale enterprise units (Indonesian Government, 2019). Additionally, the contribution of SMEs (including microenterprises) to Indonesia's national GDP reached $\mathrm{Rp} 4,321.8$ trillion (58.05\%) in 2011, climbing to Rp4,869.5 trillion or 59.08 percent in the next year. It is claimed that the value of SMEs' contribution continued to grow, to reach $60 \%$ of the national GDP in 2017 (Indonesia, 2019).

One of the prominent industries of Indonesian SMEs is the batik industry. The word batik in the Indonesian language is composed of two syllables, "ba" and "tik," meaning lots of dots. It is a product of culture and also a national icon that has been eminent at the global level, especially after UNESCO designated it an indigenous cultural heritage of Indonesia in 2009 (Heritage, 2009). The development of the batik industry has generated multiple positive impacts on the economy and socio-culture of Indonesia (Steelyana, 2012). Table 2 illustrates the continuous increase in the number of business units, production, and employment in the batik industry in Indonesia during the period 2006-2010.

\subsection{Theories and Previous Studies}

This study uses three main theories that underpin the relationship between demographic characteristics and background to ICT adoption: agency, human capital, and upper echelon theory. Agency theory states that in a company where the share ownership is widely held by several persons or entities, there is a formal bond in which one or more people who (act as "the principal(s)") will engage another person (to act as "the agent") to delegate their managerial authority and decision-making on their behalf (Jensen \& Meckling, 1976). A dilemma is likely to arise with a structure or position in the management of a company where authority is shared, wherein the agent is motivated to act in his own best interests, which can sometimes be contrary to the benefits of the principal(s). This may increase the potential for conflicts of interest that could arise from the separation of ownership and control in organizations (Hillman \& Dalziel, 2003; Kim \& Lee, 2016).
Previous studies have discussed the application of agency theory in various ICT contexts. Bahli and Rivard (2003) suggested a framework for the conceptualization and measurement of the risk construct, particularly in the context of IT outsourcing. Meanwhile, Landstrom (1993) indicated that informal venture capitalists tend to invest more in young firms and technology than formal venture capitalists. Karake (1994) examined the relationship between the level of information technology and company performance and governance issues. Karake (1995) studied the relationship between top management characteristics and the performance of information technology resources.

Second, Becker's (1964) human capital theory (HCT) developed constructs to demonstrate that the education and training of individuals does not entail merely the consumption of resources, but also needs to be considered as an investment in future productivity that will provide benefits in the form of higher incomes for business organizations. In other words, HCT argues that investment in education, training, and learning essentially functions as a driver of increased productivity and economic growth, to the benefit of individuals, organizations, and societies (Tight, 2018). Becker (1964, p. 1) conceptualized human capital as including:

activities that influence future monetary and psychic income by increasing the resources in people. These activities are called investments in human capital. The many forms of such investments include schooling, onthe-job training, medical care, migration, and searching for information about prices and incomes... all these investments improve skills, knowledge, or health, and thereby raise money or psychic incomes.

The importance and value of human capital has gained widespread acceptance among researchers. For example, the gender, educational background, and experience of smallscale business owners/managers have an effect on the chance of the business survival (Altuwaijri \& Kalyanaraman, 2020; Bruderl et al., 1992). Adom and Asare-Yeboa (2016) critically evaluated the way in which the elements of HCT influence female entrepreneurship in Ghana. In the ICT context, BarNir (2015) examined the factors associated with decisions taken by entrepreneurs to incorporate innovative technologies into new ventures.

Table 2: Development of the Batik Industry in Indonesia (2006-2010)

\begin{tabular}{|l|c|c|c|c|c|}
\hline \multirow{2}{*}{ Indicator } & \multicolumn{4}{|c|}{ Year } \\
\cline { 2 - 6 } & $\mathbf{2 0 0 6}$ & $\mathbf{2 0 0 7}$ & $\mathbf{2 0 0 8}$ & $\mathbf{2 0 0 9}$ & $\mathbf{2 0 1 0}$ \\
\hline Production & Rp 3.1 trillion & Rp 3.4 trillion & Rp 3.6 trillion & Rp 3.9 trillion & Rp 4.1 trillion \\
\hline Business Units & 48,300 & 50,715 & 53,250 & 54,411 & 55,573 \\
\hline Employment & 792,300 & 831,915 & 873,510 & 892.285 & 916,783 \\
\hline
\end{tabular}

Source: Steelyana (2012) 
Lastly, the upper echelons theory (UET) developed by Hambrick and Mason (1984) states that organizational outcomes, including strategic choices and performance levels, can be predicted by the managerial background characteristics of the leader or manager. Furthermore, UET explains idiosyncratic managerial characteristics such as psychological aspects (cognitive base and value) and observable aspects including age, functional track and career experiences, education, socioeconomic roots, financial position, and group characteristics as features of the UET framework that is considered to influence the strategic choices and performance levels of an organization (Hambrick \& Mason, 1984).

A number of studies have used UET to examine the relationship between organizational leader demographics and organizational outcomes such as firm risk-taking ( $\mathrm{Li}$ \& Tang, 2010), cash holdings (Orens \& Reheul, 2013), and financial leverage (Ting et al., 2015). In the case of SMEs, previous research applying UET has provided a reinforcing argument in explaining corporate cash policies in Belgian SMEs. It was shown that the social, psychological, and cognitive characteristics of CEOs, as proxied by various CEO demographics, could influence the policies adopted by the enterprises (Orens \& Reheul, 2013).

Besides the theoretical background of demographic characteristics, prior studies have also provided insight that has enabled the background factors related to ICT adoption to be classified into four: acceptance factors, barriers, benefits, and strategies to resolve. Many researchers such as Okundaye et al. (2019), Mokaya (2012), and Ongori and Migiro (2010) have documented these influencing factors and have included customer demands, cost reductions, and improved customer services. Previous studies such as Al-weshah and Al-zubi (2012), Tan et al. (2010), and Kannabiran (2012) have also identified various inhibiting factors encountered by SMEs when adopting and using ICT. These barriers include expensive investment in ICT, the high cost of Internet connections, slow connection speeds, and a lack of ICT support. A third category of studies conducted by Okundaye et al. (2019), Ndiege et al. (2014), and Ongori and Migiro (2010) identified strategies for resolving ICT adoption and usage problems. These strategies can be enacted by developing human capital resources (Khan et al., 2020), reducing the cost of connections, and addressing the security issues associated with using ICT tools. Researchers such as Okundaye et al. (2019), Tob-Ogu et al. (2018), and Tan et al. (2010) acknowledged the benefits of adopting ICT such as improving profit, gaining competitive advantage, improving employee interrelations, and adaptability of organizational activities. Table 3 summarizes the dimensions of background factors based on prior studies and those used in this study.

Based on the three overarching theories and previous studies, this study formulates a research framework as depicted in Figure 1. Four main hypotheses, each comprising five sub-hypotheses, are proposed to achieve the objectives of the study as follows:

H1. There are differences between demographic characteristics and acceptance factors in ICT adoption.

1a. There are differences between gender and acceptance factors in ICT adoption.

1b. There are differences between educational qualifications and acceptance factors in ICT adoption.

1c. There are differences between the age of respondents and acceptance factors in ICT adoption.

1d. There are differences between managerial status and acceptance factors in ICT adoption.

1e. There are differences between years of business experience and acceptance factors in ICT adoption.

H2. There are differences between demographic characteristics and barriers in ICT adoption.

2a. There are differences between gender and barriers to ICT adoption.

2b. There are differences between educational qualifications and barriers to ICT adoption.

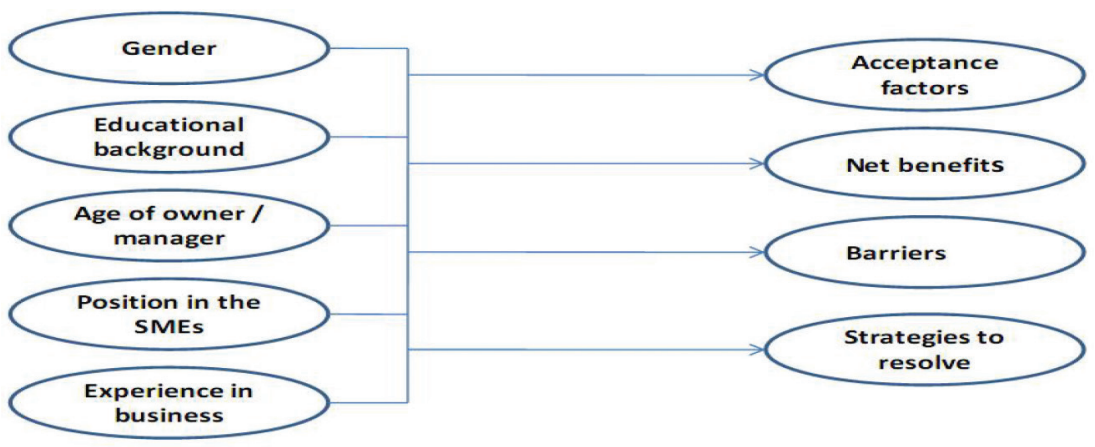

Figure 1: Research Framework 
2c. There are differences between the age of respondents and barriers to ICT adoption.

$2 d$. There are differences between managerial status and barriers to ICT adoption.

2e. There are differences between years of business experience and barriers to ICT adoption.

H3. There are differences between demographic characteristics and the benefits of ICT adoption.

3a. There are differences between gender and the benefits of ICT adoption.

3b. There are differences between educational qualifications and the benefits of ICT adoption.

$3 c$. There are differences between the age of respondents and the benefits of ICT adoption.

3d. There are differences between managerial status and the benefits of ICT adoption.

3e. There are differences between years of business experience and the benefits of ICT adoption.

H4. There are differences between demographic characteristics and strategies to resolve ICT adoption

4a. There are differences between gender and strategies to resolve ICT adoption.

4b. There are differences between educational qualifications and strategies to resolve ICT adoption.

$4 c$. There are differences between the age of respondents and strategies to resolve ICT adoption.

$4 d$. There are differences between managerial status and strategies to resolve ICT adoption.

4e. There are differences between years of business experience and strategies to resolve ICT adoption.

The next section presents the research methodology used to examine the relationship between the demographic characteristics of SMEs and the background factors of acceptance, benefits, challenges, and strategies to resolve ICT adoption.

\section{Research Method}

This study focuses specifically on batik fabric SMEs in Pekalongan, which as an area accounts for around $70 \%$ of batik production nationally. Although the precise number of batik SMEs in the area is unknown, the area authority estimates there to be about one thousand SMEs manufacturing different and unique types of batik (Pekalongan, 2018). The sample size in this study was determined using the Qualtrics calculator available in statistical textbooks, software programs, and online web pages (Qualtrics, 2018). Setting a $95 \%$ confidence level and $10 \%$ error margin produced a minimum required sample size of 96 .
Primary data were used to achieve the research objectives, which basically involved interviewing and administering questionnaires in order to obtain information from SME owners/managers. Convenience sampling was applied to distribute the questionnaires to the target population. This sampling method was selected because of the unknown sampling frame of the batik SMEs in this area, although it did not give each SME a fair chance to participate in the study. However, to improve the quality of this study, questionnaires were also distributed to the target population. This yielded 152 responses that could be processed further, and this number exceeded the required sample size. Following the Central Limit Theorem, a sample size of 30 is considered sufficient when the population is symmetric (Gujarati, 2003).

This study employed five research assistants to survey the target respondents. They were each given training in areas such as how to fill in and choose the statements in the questionnaire, behave ethically, and persuade members of the population to participate in the project. Having a target population with a low level of educational background was the primary consideration in adopting this approach.

The owner/managers of batik SMEs were given questionnaires following receipt of their intention to participate. The questionnaires consisted of two sections aimed at achieving the general purpose of the research. The first section contained five questions on the SME demographic characteristics, as indicated in the research framework (Figure 1). The second section consisted of questions measuring the owner/managers' perceptions regarding the tools, motivations, benefits, barriers, and strategies to resolve problems correspondingly when adopting ICT. Measurement of the ICT tools was conducted using a five-point rating scale comprising the following options: $0=$ not used at all, $1=$ least used, $2=$ sometimes used, $3=$ used, and $4=$ most used. The remainder of the constructs were measured using a four-point rating scale, with the responses ranging from 1 (absolutely disagree) to 4 (totally agree). This even scale provided no scope for neutrality, which some respondents may have opted for in order to avoid completing the questionnaire thoroughly.

All of the items in the questionnaire are based on the literature review discussed in section 2 (Table 3). However, the questionnaire items were discussed with a number of expert scholars in the field prior to the instrument's distribution. A pilot study was also carried out to improve the face validity of the items (Sekaran, 2003). As a result, some minor modifications were made to the words and statements in the instruments. Further, the research assistants provided a short explanation during the dissemination of the final instrument to ensure that the questionnaires were free from misinterpretation and ambiguity (Shah Alam et al., 2012). 
Table 3: Summary of the Background Factors of ICT adoption

\begin{tabular}{|c|c|}
\hline Acceptance Factors & Benefits \\
\hline Customer demands (A1) & Improving profit (C1) \\
\hline Cost reduction (A2) & Earning a competitive advantage (C2) \\
\hline Improved customer services (A3) & Improving employee interrelations (C3) \\
\hline Increased sales (A4) & Adaptability of organizational activities (C4) \\
\hline Improved internal efficiency (A5) & Decrease in staff travel cost (C5) \\
\hline Facilitate the control of the business (A6) & Monitoring of quality control systems (C6) \\
\hline Improved relations with business partners (A7) & Reducing employee overtime (C7) \\
\hline Availability of a skilled workforce (A8) & Monitoring competitors' performance (C8) \\
\hline Facilitate the growth of the business (A9) & Achieving greater customer satisfaction (C9) \\
\hline Managing a significant volume of information (A10) & Reducing the cost of communication (C10) \\
\hline Develop new markets (A11) & Enhancing the company's image (C11) \\
\hline Demands from SME associations (A12) & Facilitating payments to third parties (C12) \\
\hline Pressure from trade associations (A13) & Increasing efficiency (C13) \\
\hline Pressure from the government (A14) & Complying with government regulation (C14) \\
\hline Pressure from labor unions (A15) & Improving information and knowledge management (C16) \\
\hline Pressure from staff (A16) & Encouraging inter- and intra-business transactions (C17) \\
\hline \multirow[t]{2}{*}{ Pressure from competitors (A17) } & Linking to local and global supply chains (C18) \\
\hline & Reducing operational costs (C19) \\
\hline Barriers & Increasing business processes productivity (C20) \\
\hline Expensive investment in ICT (B1) & Facilitating quick information search (C21) \\
\hline Expensive Internet connection (B2) & Enhancing ability to search market information (C22) \\
\hline Slow connection speed (B3) & Accessibility to global markets (C23) \\
\hline Lack of ICT support (B4) & Sharing and learning of new business practices (C15) \\
\hline \multicolumn{2}{|l|}{ Lack of staff knowledge to use ICT (B5) } \\
\hline Lack of security in the use of ICT (B6) & Strategies to resolve \\
\hline Unawareness of the benefits of ICT (B7) & Developing human capital resources (D1) \\
\hline Lack of financial resources (B10) & Reducing the cost of connection (D2) \\
\hline High failure of using ICT (B11) & Addressing security issues (D3) \\
\hline Lack of qualified staff employed (B12) & Improving speed and connectivity (D4) \\
\hline Lack of strategies for ICT adoption (B13) & Increasing access to financing organizations (D5) \\
\hline ICT does not satisfy the needs (B14) & Using alternate power sources (D6) \\
\hline Unclear or unsure of which ICT tools to adopt (B15) & Enabling ICT policy (regulatory framework) (D7) \\
\hline \multicolumn{2}{|l|}{ Resistance to change (B16) } \\
\hline \multicolumn{2}{|l|}{ Expensive staff training (B17) } \\
\hline Lack of information on benefits (B18) & \\
\hline
\end{tabular}


This study applied factor analysis with Varimax rotation in order to reduce and summarize the items of each construct. The results indicate the factors that have an antiimage correlation score with other factors of at least 0.50 , thus suggesting good factorability. The Kaiser-MeyerOlkin (KMO) value for measuring the adequacy of the sampling was 0.7 , which is higher than the recommended value of 0.6. The chi-squared values of Bartlett's test were significant. Small values (less than 0.05) for the significance level indicate that the factor analysis is suitable to process further. Based on these indicators, 11 acceptance factors, 23 benefit items, 13 barrier measures, and nine factors of strategies to resolve ICT adoption were considered appropriate for the construct validity. Furthermore, these factors had high internal consistency reliability: the lowest value of Cronbach's alpha was 0.755 for barriers, while the highest was for the construct of strategies to resolve at 0.835 . Nunnally (1978) recommended a Cronbach's alpha value of 0.7 or higher as a reliable benchmark.

\section{Results and Discussions}

\subsection{Demographic Profile}

The demographic profile in Table 4 contains the respondent characteristics in terms of their gender, age, position in the SME, educational background, and number of years' experience in business. Based on frequency distribution, Table 4 shows that $65.8 \%$ of the SME respondents surveyed were males $(n=100)$ and $34.2 \%$ were females $(n=52)$. This result may indicate that business owners are more likely to be male. In addition, there was a similar distribution of the respondents surveyed based on age group. There were identical numbers of SME respondents aged below $21(n=43)$ and over 41 years, while the 21-30 age group accounted for $17.8 \%(\mathrm{n}=27)$ of respondents, and $25.7 \%(n=39)$ were in the $31-40$ age group. These findings may suggest that the majority of SMEs surveyed are managed by either young or old individuals.

The results also indicate that $41.4 \%(n=63)$ of the respondents were the owners of the SMEs, 32.9\% $(n=50)$ were other staff, $17.8 \%(n=27)$ were both owners and managers, and $7.9 \%$ (12) were managers of the SMEs. This result may suggest that the majority of the respondents have decisive and crucial positions in relation to the adoption of ICT in their daily business.

Table 4 further shows that the majority $(40.1 \%$ or $n=$ 61) of the respondents from batik SMEs in Pekalongan held an Indonesian middle-high school certificate, $32.9 \%$ ( $\mathrm{n}=$ $50)$ were in the high school group, $20.4 \%(n=31)$ were in the elementary school group, and a total of $6.5 \%(n=10)$ were in the diploma and undergraduate groups. This result may imply that a majority of the respondents had a lack of education, which might act as a barrier to the implementation of ICT in their firms.

Finally, the results indicate that $44.1 \%(n=67)$ of the respondents had fewer than 11 years' experience in business, $37.5 \%(n=57)$ had $11-20$ years' business experience, $15.8 \%$ $(n=24)$ had 21-30 years' experience, and 2.6\% $(n=4)$ had more than 30 years' business experience. These results suggest that the owners/managers of SMEs have enough experience in business to recognize the importance of ICT adoption in their SMEs.

Table 4: Demographic Profile

\begin{tabular}{|c|c|c|}
\hline Gender & Frequency & Percent \\
\hline 1. Male & 100 & 65.8 \\
\hline 2. Female & 52 & 34.2 \\
\hline Total & 152 & 100.0 \\
\hline \multicolumn{3}{|l|}{ Age } \\
\hline 1. $<21$ years & 43 & 28.3 \\
\hline 2. $21-30$ years & 27 & 17.8 \\
\hline 3. $31-40$ years & 39 & 25.7 \\
\hline 4. $>41$ years & 43 & 28.3 \\
\hline Total & 152 & 100.0 \\
\hline \multicolumn{3}{|l|}{ Position } \\
\hline 1. Owner & 63 & 41.4 \\
\hline 2. Manager & 12 & 7.9 \\
\hline 3. Owner and Manger & 27 & 17.8 \\
\hline 4. Other (staff) & 50 & 32.9 \\
\hline Total & 152 & 100.0 \\
\hline \multicolumn{3}{|l|}{ Educational background } \\
\hline 1. Elementary school & 31 & 20.4 \\
\hline 2. Middle high school & 61 & 40.1 \\
\hline 3. High school & 50 & 32.9 \\
\hline 4. Diploma & 6 & 3.9 \\
\hline 5. Undergraduate & 4 & 2.6 \\
\hline Total & 152 & 100.0 \\
\hline \multicolumn{3}{|l|}{ Experience in business } \\
\hline 1. < 11 years & 67 & 44.1 \\
\hline 2. $11-20$ years & 57 & 37.5 \\
\hline 3. $21-30$ years & 24 & 15.8 \\
\hline 4. $>30$ years & 4 & 2.6 \\
\hline Total & 152 & 100.0 \\
\hline
\end{tabular}




\subsection{SMEs' ICT Tools}

In addition to the demographic profile of the respondents, the results in this study indicate the ICT tools commonly used by SMEs. Table 5 contains the responses on the use of ICT tools. The results reveal that the modern tools of smartphones $(\mathrm{M}=3.29)$, Internet connection $(\mathrm{M}=3.2)$, and laptop ( $\mathrm{M}=2.62)$ to be the IT tools most commonly used in SMEs. Inversely, SMEs rarely used traditional tools such as telex $(\mathrm{M}=1.82)$, scanners $(\mathrm{M}=1.86)$, and typewriters $(\mathrm{M}=1.95)$ in their business respectively.

This frequent use of modern equipment compared to traditional means indicates that SMEs have applied sophisticated tools and are well prepared to adopt ICT. Low costs and maintenance expenses may be the main considerations in their decisions to use these tools. In addition, modern tools often perform multiple functions, which means they can easily replace traditional tools. For example, a smartphone with Internet applications can be used to scan data and send it to other parties, thus replacing a tool such as telex. Furthermore, these sophisticated tools can help SME management to plan, coordinate, and monitor their daily work.

These results are similar to those reported by previous studies. Mokaya (2012) revealed that most SMEs use necessary communication tools such as cellphones and the Internet. Bayo-Moriones, Billón, and Lera-López (2013) also identified servers, laptops, iPads, cellphones, wireless intranet, and security systems as the most frequently used technological tools. Furthermore, Kiveu and Ofafa (2013), in their study, showed that the ICT tools used on a day-today basis include cellphones, televisions, iPads, notepads, and computers. Lastly, Deloitte (2015) revealed that around one-third of Indonesia's SMEs are still offline and thus are missing out on most of the benefits of digital technologies.

\subsection{Hypothesis Testing}

This study employs the non-parametric statistical tools of the Mann-Whitney and Kruskal-Wallis tests to examine the objective of the study. The Mann-Whitney test is a type of inferential statistical test that is used here to determine whether there is a significant difference between the median or ranking of two groups (males and females) in the constructs of acceptance factors, benefits, challenges, and strategies to resolve ICT adoption. A Kruskal-Wallis test is an inferential statistic test used to examine whether there are any statistically significant differences among the medians of demographic characteristics. The initial data processing steps indicate that the data in this study do not meet the underlying assumptions for parametric statistical tools. Primarily, the data study resulted in unequal variance among demographic characteristics for the constructs of this study. The next sections provide and elaborate on the results of the hypothesis testing.

Table 5: Types of ICT Tools

\begin{tabular}{|c|c|c|c|c|c|c|c|}
\hline \multirow[b]{2}{*}{ Tools } & \multicolumn{5}{|c|}{ Count (Percentages) } & \multirow[b]{2}{*}{ Mean } & \multirow[b]{2}{*}{$\begin{array}{c}\text { Std. } \\
\text { Deviation }\end{array}$} \\
\hline & $\begin{array}{l}\text { Mostly } \\
\text { used }\end{array}$ & Used & $\begin{array}{c}\text { Sometime } \\
\text { used }\end{array}$ & $\begin{array}{l}\text { Rarely } \\
\text { used }\end{array}$ & $\begin{array}{c}\text { Not used } \\
\text { at all }\end{array}$ & & \\
\hline Computer desk & $31(20.4)$ & $51(33.6)$ & 25 (16.4) & $45(29.6)$ & $0(0.0)$ & 2.450 & 1.120 \\
\hline Laptops & $38(25.0)$ & $48(31.6)$ & 36 (23.7) & $30(19.7)$ & $0(0.0)$ & 2.620 & 1.067 \\
\hline Fax & $8(5.3)$ & $49(32.2)$ & $21(13.8)$ & $72(47.4)$ & $2(1.3)$ & 1.930 & 1.030 \\
\hline Printer & $12(7.9)$ & $50(32.9)$ & $34(22.4)$ & $55(36.2)$ & $1(0.7)$ & 2.110 & 1.013 \\
\hline Copy machine & $26(17.1)$ & $32(21.1)$ & $36(23.7)$ & $56(36.8)$ & $2(1.3)$ & 2.160 & 1.140 \\
\hline Smartphone & $73(48.0)$ & $57(37.5)$ & $16(10.5)$ & $5(3.3)$ & $1(0.7)$ & 3.290 & 0.835 \\
\hline Internet & $61(40.1)$ & $65(42.8)$ & $22(14.5)$ & $4(2.6)$ & $0(0.0)$ & 3.200 & 0.783 \\
\hline Website & $31(20.4)$ & $51(33.6)$ & $45(29.6)$ & $24(15.8)$ & $1(0.7)$ & 2.570 & 1.007 \\
\hline Telephone & $20(13.2)$ & $26(17.1)$ & $51(33.6)$ & $54(35.5)$ & $1(0.7)$ & 2.070 & 1.040 \\
\hline Telex & $11(7.2)$ & $31(20.4)$ & 30 (19.7) & $79(52.0)$ & $1(0.7)$ & 1.820 & 1.006 \\
\hline Scanner & $11(7.2)$ & $40(26.3)$ & $18(11.8)$ & $83(54.6)$ & $0(0.0)$ & 1.860 & 1.042 \\
\hline Typewriter & $22(14.5)$ & $25(16.4)$ & $28(18.4)$ & $77(50.7)$ & $0(0.0)$ & 1.950 & 1.120 \\
\hline IT infrastructure & $18(11.8)$ & $42(27.6)$ & $40(26.3)$ & $51(33.6)$ & $1(0.7)$ & 2.160 & 1.045 \\
\hline Business app & $31(20.4)$ & $36(23.7)$ & $49(32.2)$ & $35(23.0)$ & $1(0.7)$ & 2.400 & 1.075 \\
\hline
\end{tabular}


Hadri KUSUMA, Muafi MUAFI, Hendy Mustiko AJI, Sigit PAMUNGKAS /

Journal of Asian Finance, Economics and Business Vol 7 No 10 (2020) 969-980

Table 6: Results of Hypothesis Testing

\begin{tabular}{|l|c|c|c|c|c|}
\hline \multirow{2}{*}{$\begin{array}{l}\text { Background } \\
\text { Factors }\end{array}$} & Gender & Age & Status & $\begin{array}{c}\text { Educational } \\
\text { qualification }\end{array}$ & $\begin{array}{c}\text { Experience in } \\
\text { Business }\end{array}$ \\
\cline { 2 - 6 } & $\begin{array}{c}\text { Z-test } \\
(\mathbf{p} \text {-value) }\end{array}$ & $\begin{array}{c}\text { Chi-Square } \\
(\mathbf{p} \text {-value) }\end{array}$ & $\begin{array}{c}\text { Chi-Square } \\
(\mathbf{p} \text {-value) }\end{array}$ & $\begin{array}{c}\text { Chi-Square } \\
(\mathbf{p} \text {-value) }\end{array}$ & $\begin{array}{c}\text { Chi-Square } \\
\text { ( } \text {-value) }\end{array}$ \\
\hline Acceptance & -1.609 & 19.612 & 28.754 & 4.895 & 6.623 \\
& $(0.108)$ & $(0.000)^{*}$ & $(0.000)^{*}$ & $(0.180)$ & $(0.085)$ \\
\hline Barriers & -0.294 & 5.613 & 2.359 & 2.971 & 11.45 \\
& $(0.768)$ & $(0.132)$ & $(0.501)$ & $(0.563)$ & $(0.010)^{* *}$ \\
\hline Benefits & -1.314 & 31.937 & 17.144 & 5.548 & 12.535 \\
& $(0.189)$ & $(0.000)^{*}$ & $(0.001)^{*}$ & $(0.236)$ & $(0.006)^{*}$ \\
\hline Strategies & -0.545 & 28.395 & 19.849 & 5.077 & 15.641 \\
& $(0.586)$ & $(0.000)^{*}$ & $(0.000)^{*}$ & $(0.279)$ & $(0.001)^{*}$ \\
\hline
\end{tabular}

${ }^{*} p<0.01,{ }^{* *} p<0.05$

Table 6 presents the Z-test and Chi-Square and their p-values regarding age groups, status in SMEs, educational qualification, and experience in business, along with the background factors of ICT adoption. The Chi-Square results indicate that generally there are differences between the demographic characteristics of the age groups (chi-square $=19.612, \mathrm{p}<.01$ ) and status in SMEs (chi-square $=28.754, \mathrm{p}<0.01$ ) towards the acceptance factors of ICT adoption. Differences also exist between experience in business groups (chi-square $=11.450, \mathrm{p}<.05$ ) and barriers to ICT adoption. Furthermore, the benefits of ICT adoption vary among the demographic characteristics of the age groups (chi-square $=31.937, \mathrm{p}<0.01$ ), status in SMEs (chi-square $=17.114, \mathrm{p}<0.01$ ), and experience in business groups (chi-square $=12.535, \mathrm{p}<.01$ ). Lastly, the strategies for resolving ICT adoption and usage problems are different among the demographic characteristics of the age groups (chi-square $=28.395, \mathrm{p}<0.01$ ), status in SMEs (chisquare $=19.849, \mathrm{p}<0.01$ ), and experience in business groups (chi-square $=15641, \mathrm{p}<.01$ ).

The results of this study indicate that all of the hypotheses related to gender ( $\mathrm{H} 1 \mathrm{a}, \mathrm{H} 2 \mathrm{a}, \mathrm{H} 3 \mathrm{a}$, and $\mathrm{H} 4 \mathrm{a})$ are rejected. The p-values of the Z-tests in Table 6 are not significant. Therefore, there is no variation between the two genders in terms of their perception of acceptance factors, benefits, and strategies for resolving ICT adoption problems. A possible explanation for this finding may be that both men and women were members of batik SMEs, where their activities are similar. These may also attribute the finding to the respondents having had prior experience of ICT use. Previous engagement in ICT translates to similar ICT experience and hence to similar perceptions. More specifically, the SMEs reporting high ICT usage tended to have more positive perceptions of ICT. Therefore, men express similar views on the adoption of technology and use ICT at a similar frequency to women. Furthermore, members of both genders in the SMEs engage in ICT for the purpose of planning, coordinating, and controlling their daily activities. They also have similar experience with the functions. They use ICT to communicate with others by e-mail, interact with others in chat rooms, and search for information related to their business activities.

All of the hypotheses related to educational backgrounds ( $\mathrm{H} 1 \mathrm{~b}, \mathrm{H} 2 \mathrm{~b}, \mathrm{H} 3 \mathrm{~b}$, and $\mathrm{H} 4 \mathrm{~b})$ are rejected, and the P-values of the Chi-squares in Table 6 are not significant. Hence, there are no differences between educational qualifications in terms of the background factors of acceptance factors, benefits, barriers, and strategies to resolve ICT adoption problems. This result can be attributed to the homogeneity in educational background among the research participants. The demographic profile data indicate that $93.55 \%$ of the respondents do not hold university degrees: they instead have formal education in the form of senior high school or lower. This is likely to contribute to them having similar perceptions of the background factors of ICT adoption. Additionally, these low educational backgrounds can serve as barriers to understanding and conducting ICT adoption. Therefore, the government needs to educate SME management to improve their knowledge, motivation, and willingness to adopt ICT. The government has various means it can use to solve this problem, such as through training and special benefits, easy access, and other incentives for SMEs.

Different from the demographic characteristics of gender and educational qualification, the hypotheses related to age compositions ( $\mathrm{H} 1 \mathrm{c}, \mathrm{H} 3 \mathrm{c}$, and $\mathrm{H} 4 \mathrm{c}$ ) are in general supported. There are differences between the age groups in terms of the background factors of ICT adoption. Learning theory may underline the importance of this finding. Learning is the 
process by which an individual in top management or the owner of an SME acquires skill, knowledge, and ability and gains an understanding of the functions and use of ICT. Over time, there is a significant improvement in the perceptions of SMEs in terms of acceptance factors, benefits, and strategies to resolve ICT adoption problems.

Additionally, younger managers/owners are likely to have completed their formal education more recently than older managers/managers, and thus their understanding of ICT may be superior and more up-to-date. This means that younger managers/owners of SMEs find it easier to understand the background factors of ICT adoption. Lastly, older managers/owners are more likely to stick to the organizational status quo, be less able to learn new technology, and more likely to avoid risky decisions. Therefore, older managers/owners have greater difficulty accepting, adopting, and implementing ICT in their business.

This study supports the hypotheses related to managerial status in SMEs (H1d, H3d, and H4d). However, there are differences between managerial status with regard to acceptance factors, benefits, and strategies to resolve ICT adoption problems. The demographic data in this study indicate that around $67.1 \%$ of the survey respondents were managers/owners, thus implying that the members of top management are critical players within their respective SME organizations. Therefore, it is plausible to consider the experience and authorization of top management in this result. Top management with a higher level of experience may be more likely to adopt ICT in their SME business than those with less experience. This tremendous management experience can also enable information on benefits, barriers, and strategies for resolving ICT adoption and usage problems to be spread across the entire firm more quickly and easily. Besides their management experience, members of the top management of SMEs have high status and power to authorize a range of decisions, including on the adoption of ICT. Owners/managers can also influence, enhance, and direct their subordinates within an SME to achieve their goals through the use of ICT tools.

Lastly, $\mathrm{H} 2 \mathrm{e}, \mathrm{H} 3 \mathrm{e}$, and $\mathrm{H} 4 \mathrm{e}$ indicating years in business engagement are supported. There are differences between years of business experience with regard to the barriers, benefits, and strategies to resolve ICT adoption. The years in business experience represent the length of time that SMEs have been operating in the market. At the same time, these years serve as indicators of the level of accumulated knowledge and experience of SMEs. The data in this study show that $18.4 \%$ of the respondents working in SMEs had more than 20 years' experience, while $44.1 \%$ had less than 11 years' experience and knowledge. By adopting ICT, older SMEs can adapt better to new environments than younger SMEs. Older SMEs are thus able to discover how to operate efficiently, coordinate, and organize various firm resources, speed up their production process, and the improve the quality of their products. However, the usages and functions of ICT can act as a severe barrier to older SMEs due to a lack of human resources and supporting infrastructure, and expensive investments and maintenance.

\section{Conclusions, Implications, and Future Studies}

In the midst of the current global economic environment, ICT is attracting an increasing amount of attention as it is held to be one of the prominent forces in driving economic growth (Nyandoro, 2016). Despite the many potential challenges to its development and adoption processes, ICT is nevertheless considered as one of the key resources for many business organizations to improve their business process management. Furthermore, ICT is a necessary means for dealing with today's digital phenomenon, where information flows and proliferates, along with the development of more advanced and flexible communication channels (Wart et al., 2017).

This study has tackled its four objectives by investigating, through a questionnaire survey, the relationship between SME demographic characteristics with regard to adoption factors and their dimensions of acceptance factors, benefits, challenges, and strategies for resolving ICT adoption and usage problems. The study's findings are valuable to all stakeholders in SMEs, particularly owners/managers and policymakers, regarding issues related to ICT adoption. The owners/managers of SMEs can take priority steps to support the adoption of ICT in their organizations by identifying the most suitable technology and considering the most important acceptance factors, main benefits, and appropriate tactics for addressing the potential constraints of ICT. Given the significant role played by SMEs and the challenges posed by Industry 4.0, the Indonesian government needs to make a strong commitment to supporting SME entrepreneurs by building e-commerce platforms for SMEs, creating technology banks (centers) to enhance their ability to acquire technology, and by providing mentoring support to drive innovation.

This study acts as a good starting point in the investigation of relationships between demographic characteristics and ICT adoption. Future studies may be extended in various aspects. First, since the sample comprised only Batik Pekalongan SMEs, a heterogeneous sample that includes other types of SMEs or other batik SMEs may yield different results. Therefore, an extensive study with a more comprehensive and different sample could be useful. A future study could also explore the leadership style present within SMEs with 
regard to ICT adoption. The type of leadership style plays a critical role in how SME owners/managers run their business, including the use of ICT to gain competitive advantage. The low educational levels of the owners/managers of the SMEs in this study could result in them adopting different leadership styles from those with a graduate educational background. Finally, this study has addressed ICT in general and has shown that the investigation of specific ICT tools such as Internet-based technology, social media, software applications, and so on can be meaningful.

\section{References}

Adom, K., \& Asare-Yeboa, I. (2016). An evaluation of human capital theory and female entrepreneurship in sub-Sahara Africa. International Journal of Gender and Entrepreneurship, 8(4), 402-423. https://doi.org/https://doi.org/10.1108/IJGE-122015-0048

Al-weshah, G. a, \& Al-zubi, K. (2012). Study of Smes in Jordanian Communication. Global Journal of Business Research, 6(3), $1-16$.

Altuwaijri, B. M., \& Kalyanaraman, L. (2020). CEO EducationPerformance Relationship: Evidence from Saudi Arabia. Journal of Asian Finance, Economics and Business, 7(8), 259268. https://doi.org/10.13106/jafeb.2020.vol7.no8.259

Bahli, B., \& Rivard, S. (2003). The information technology outsourcing risk: A transaction cost and agency theory-based perspective. Journal of Information Technology, 18(3), 211221. https://doi.org/10.1080/0268396032000130214

BarNir, A. (2015). Starting technologically innovative ventures: reasons, human capital, and gender. Management Decision, 50(3), 399-419. https://doi.org/http://dx.doi. org/10.1108/0025174121121620

Bayo-Moriones, A., Billón, M., \& Lera-López, F. (2013). Perceived performance effects of ICT in manufacturing SMEs. Industrial Management and Data Systems, 113(1), 117-135. https://doi. org/10.1108/02635571311289700

Becker, G. (1964). Human capital: A theoretical and empirical analysis, with special reference to education. National Bureau of Economic Research/Columbia University Press.

Bruderl, J., Preisendorfer, P., \& Ziegler, R. (1992). Survival Chances of Newly Founded Business Organizations. American Sociological Review, 57(2), 227-242. https://doi. org/10.2307/2096207

Corporate Finance Institute. (2019). What are Small and Mediumsized Enterprises (SMEs)? Corporate Finance Institute. https:// corporatefinanceinstitute.com/resources/knowledge/other/ small-and-medium-sized-enterprises-smes/

Delloite. (2015). Deloitte Report: SMEs Powering Indonesia's success. Dellloites Access Economics. https://www2.deloitte. $\mathrm{com} / \mathrm{id} / \mathrm{en} / \mathrm{pages} /$ financial-advisory/articles/smes-poweringindonesia-success-report.html
Gujarati, D. N. (2003). Essentials of Econometrics (4th ed.). New York, NY: McGraw-Hill.

Hambrick, D. C., \& Mason, P. a. (1984). Echelons: of Reflection The Its Organization as Top a. The Academy of Management Review, 9(2), 193-206. https://doi.org/10.2307/258434

Heritage, I. C. (2009). Indonesian Batik. Convention for the Safeguarding of the Intangible Cultural Heritage. https://ich. unesco.org/en/RL/indonesian-batik-00170

Hillman, A. J., \& Dalziel, T. (2003). Boards of Directors and Firm Performance: Integrating Agency and Resource Dependence Perspectives. The Academy of Management Review, 28(3), 383-396. https://doi.org/10.2307/30040728

Indonesian Government. (2009). Law of the Republic of Indonesia Number 20 concerning Micro, Small, and Medium Enterprises. Retrieved April 19, 2019 from: https:/www.ojk.go.id/ sustainable-finance/id/peraturan/undang-undang/Documents/ Undang-Undang\%20Nomor\%2020\%20Tahun $\% 202008 \% 20$ Tentang\%20Usaha\%20Mikro, \%20Kecil,\%20dan $\% 20$ Menengah.pdf

Indonesian Government. (2019). Development of Data on Micro, Small, Medium Enterprises and Large Enterprises Years 2016 - 2017. Retrieved April 22, 2019 from: http://www.depkop. go.id/uploads/laporan/1549946778_UMKM 2016-2017 rev. pdf

Jensen, M. C., \& Meckling, W. H. (1976). Theory of the firm: managerial behavioragency and ownership structure. Journal of Financial Economics, 3(4), 305-360. https://doi. org/10.1016/0304-405X(76)90026-X

Kannabiran, G. (2012). Enablers and inhibitors of advanced information technologies adoption by SMEs: An empirical study of auto ancillaries in India. Journal of Enterprise Information Management, 25(2), 186-209. https://doi. org/10.1108/17410391211204419

Karake, Z. A. (1994). Relative Information Technology Index (RITI): Logistics Information Management, 7(4), 6-14. https:// doi.org/10.1108/09576059410066363

Karake, Z. A. (1995). Information technology performance: agency and upper echelon theories. Management Decision, 33(9), 3037. https://doi.org/doi:10.1108/00251749510098964

Khan, U., Zhang, Y., \& Salik, M. (2020). The Financial Performance of Korean Manufacturing SMEs: Influence of Human Resources Management. Journal of Asian Finance, Economics and Business, 7(8), 599-611. https://doi.org/10.13106/ jafeb.2020.vol7.no8.599

Kim, S.-S., \& Lee, J. H. (2016). The Marginal Value of Cash and Agency Conflicts in Korean Firms. Journal of Asian Finance, Economics and Business, 3(4), 5-16. https://doi.org/10.13106/ jafeb.2016.vol3.no4.5

Kiveu, M., \& Ofafa, G. (2013). Enhancing market access in Kenyan SMEs using ICT. Global Business and Economics Research Journal, 2(9), 29-46. http://www.journal.globejournal.orghttp// www.journal.globejournal.org 
Landstrom, H. (1993). Agency Theory and Its Application to Small Firms: Evidence from the Swedish Venture Capital Market. Journal of Entrepreneurial Finance, 2(3), 203-218.

Li, J., \& Tang, Y. (2010). CEO Hubris and Firm Risk Taking in China: The Moderating Role of Managerial Discretion. Academy Of Management Journal, 53(41), 45-68. https://doi. org/10.1111/1467-9442.00135

Meggiolaro, S. (2018). Information and communication technologies use, gender and mathematics achievement: evidence from Italy. Social Psychology of Education, 21(2), 497-516. https://doi.org/10.1007/s11218-017-9425-7

Mokaya, S. (2012). The Adoption of Information and Communication Technology by Small Enterprises in Thika Municipality, Kenya. International Journal of Business and Social Science, 3(13), 172-177.

Ndiege, J., Herselman, M., \& Flowerday, S. (2014). Absorptive Capacity and Information Technology Adoption Strategies: A Study of SMEs in Kenya. The African Journal of Information Systems Volume, 6(4), 140-155.

Nguyen, A. H., Ha, H. H., \& Nguyen, S. La. (2020). Determinants of Information Technology Audit Quality: Evidence from Vietnam. Journal of Asian Finance, Economics and Business, 7(4), 41-50. https://doi.org/10.13106/jafeb.2020.vol7.no4.41

Nunnally, J. C. (1978). Psychometric Theory (2nd ed.). New York, NY: McGraw-Hill.

Okundaye, K., Fan, S. K., \& Dwyer, R. J. (2019). Impact of information and communication technology in Nigerian small-to medium-sized enterprises. Journal of Economics, Finance and Administrative Science, 24(47), 29-46. https://doi. org/10.1108/JEFAS-08-2018-0086

Ongori, H., \& Migiro, S. O. (2010). Information and communication technologies adoption in SMEs: literature review. Journal of Chinese Entrepreneurship, 2(1), 93-104. https://doi. org/10.1108/17561391011019041

Ono, H., \& Zavodny, M. (2005). Gender Differences in Information Technology Usage: a U.S-Japan comparison. Sociological Perspectives, 48(1), 105-133. https://doi.org/10.4018/978-187828-991-9.ch151

Orens, R., \& Reheul, A. M. (2013). Do CEO demographics explain cash holdings in SMEs? European Management Journal, 31(6), 549-563. https://doi.org/10.1016/j.emj.2013.01.003
Pekalongan, P. (2018). Regent Working Visit to Balikpapan, Establish UMKM Cooperation. http://pekalongankab.go.id/ v2/berita-lokal/10464-bupati-kunker-ke-balikpapan-jalinkerjasama-umkm

Qualtrics. (2018). Sample Size Calculator. https://www.qualtrics. com/blog/calculating-sample-size/

Sekaran, U. (2003). Research Methods: A Skill Building Approach (4th ed.). Hoboken, NJ: John Wiley \& Sons, Inc.

Shah Alam, S., Fauzi Mohd Jani, M., Asiah Omar, N., Hossain, T., \& Ahsan, M. N. (2012). Empirical Study of Theory of Reason Action (TRA) Model for ICT Adoption among the Malay Based SMEs in Malaysia. Business Management and Strategy, 3(2), 43-53. https://doi.org/10.5296/bms. v3i2.2911

Steelyana, E. (2012). Batik, A Beautiful Cultural Heritage that Preserve Culture and Supporteconomic Development in Indonesia. Binus Business Review, 3(1), 116. https://doi. org/10.21512/bbr.v3i1.1288

Tan, K. S., Chong, S. C., Lin, B., \& Eze, U. C. (2010). Internetbased ICT adoption among SMEs: Demographic versus benefits, barriers, and adoption intention. Journal of Enterprise Information Management, 23(1), 27-55. https://doi.org/http:// dx.doi.org/10.1108/17410391011008897

Tight, M. (2018). Human and Social Capital and Their Application in Higher Education Research. Theory and Method in Higher Education Research, 4, 209-223. https:/doi.org/10.1108/ s2056-375220180000004013

Ting, I. W. K., Azizan, N. A. B., \& Kweh, Q. L. (2015). Upper Echelon Theory Revisited: The Relationship between CEO Personal Characteristics and Financial Leverage Decision. Procedia - Social and Behavioral Sciences, 195, 686-694. https://doi.org/10.1016/j.sbspro.2015.06.276

Tob-Ogu, A., Kumar, N., \& Cullen, J. (2018). ICT adoption in road freight transport in Nigeria - A case study of the petroleum downstream sector. Technological Forecasting and Social Change, 131(November 2016), 240-252. https://doi. org/10.1016/j.techfore.2017.09.021

Van Wart, M., Roman, A., Wang, X. H., \& Liu, C. (2017). Integrating ICT adoption issues into e-leadership theory. Telematics and Informatics, 34(5), 527-537. https://doi.org/10.1016/j. tele.2016.11.003 